\title{
Virulence Factors in Staphylococcus aureus and Quality of Raw Milk from Dairy Cows in a Semiarid Region of Northeastern Brazil
}

\author{
Renata de Moraes Peixoto Araújo', Rodolfo de Moraes Peixoto' ${ }^{2}$ \\ Luciana Jatobá e Silva Peixoto², Gisele Veneroni Gouveia' \& Mateus Matiuzzi da Costa'
}

\begin{abstract}
Background: Milk quality is considered unsatisfactory in Brazil due to factors of a social, economic, cultural, and climatic nature. Mastitis is the main disease that affects dairy herds. Microorganisms of the genus Staphylococcus are the most frequently isolated pathogens in cases of mastitis in bovines. Staphylococcus aureus requires more attention because they have the ability to develop resistance to antimicrobials used in the treatment of mastitis. Thus, the aim of the present study was to evaluate virulence factors in isolates of $S$. aureus as well as analyze the hygienic-sanitary quality of raw milk produced on dairy farms in a semiarid region of northeastern Brazil.

Material, Methods \& Results: Samples were taken from milk containers at 44 properties. Fifty-eight isolates of Staphylococcus spp. were analyzed and genotypically identified as $S$. aureus. In the phenotypic characterization, 56.8\% (33/58) of the isolates demonstrated moderate biofilm production. In the genotypic characterization (icaA, icaD and bap genes), icaA was the most representative among the isolates. No resistance to cephalothin or oxacillin was found, but $62 \%(36 / 58)$ of the isolates exhibited resistance to ampicillin, amoxicillin, and penicillin. In the genotypic evaluation in response to $\beta$-lactam antibiotics, 50\% (29/58) of the isolates exhibited the blaZ gene. Total bacterial counts were determined based on the standard plate count and flow cytometry, for which a significant positive correlation was found $(\mathrm{r}=0.61, P<0.01)$. The somatic cell count was also performed using flow cytometry and demonstrated that $6.8 \%(3 / 44)$ of the properties had values above one million cells per mL. The analysis of Staphylococcus spp. revealed that 20\% (9/44) of the properties had significant counts for the production of staphylococcal enterotoxins. Regarding total coliforms, 56.8\% (25/44) of the milk analyzed had counts above $1.0 \times 103 \mathrm{CFUs} / \mathrm{mL}$. There were no cases of the isolation of Pseudomonas spp. Streptococcus spp. was isolated on $6.8 \%$ (3/44) of the properties. The results of the sequencing revealed one isolate to be Lactococcus lactis and two to be Enterococcus spp.

Discussion: None of the 58 isolates of S. aureus was classified as negative in the phenotypic characterization of biofilmforming capacity, which suggests the presence of genes involved in this process. Studies have shown that the molecular techniques used to identify ica genes encoding biofilm synthesis are very important for the identification of virulent strains. The isolates demonstrated resistance to $\beta$-lactam antibiotics of the class of penicillins, which are the most widely employed antimicrobial agents for the treatment of diseases in dairy herds. The presence of the blaZ gene in $50 \%$ of the isolates is in agreement with data reported in other studies developed in northeastern Brazil. In 50\% (29/58) of the isolates, the presence of the blaZ gene was not observed. Of these, (8/29) were resistant to ampicillin, amoxicillin and penicillin. This is due to the existence of other bacterial mechanisms. Research has shown that some isolates possessed three mechanisms (blaZ, mecA and $m s r A$ ) of antimicrobial resistance simultaneously. The results of the quality analyses demonstrate that some properties produce milk of low quality, which underscores the need for management strategies directed at reducing the contamination of the product.
\end{abstract}

Keywords: raw milk, bovine, mastitis, Staphylococcus aureus, quality. 


\section{INTRODUCTION}

Staphylococcus aureus is considered the main pathogen in cases of bovine mastitis [43] and its prevalence may be related to the presence of biofilm, which diminishes susceptibility to antimicrobial agents [30]. The resistance of these microorganisms to $\beta$-lactam antibiotics may also be related to presence of certain genes [5] responsible for regulating the synthesis of enzymes (e.g., beta-lactamases) mediated by the blaZ gene [33].

Bovine mastitis has a huge impact on milk production. Thus, knowledge on virulence factors is important. It is also important to use indicators for monitoring the quality of raw milk, such as the total bacterial count (TBC) and somatic cell count (SCC) [16]. TBC is a direct measure of contamination and SCC is an indirect measure of mastitis in a herd [8]. Other indicators are important to the evaluation of refrigerated raw milk, such as the psychrotrophic bacterial count, especially species of the genus Pseudomonas [34], total coliform count as an indicator of environmental and fecal contamination [18], and an evaluation of the presence of mastitis-causing pathogens, such as Staphylococcus aureus and Streptococcus agalactiae [19].

Considering the impact of bovine mastitis on milk quality, the aim of the present study was to perform phenotypic and genotypic analyses of isolates of $S$. aureus with regard to the production of biofilm and resistance to antimicrobial agents as well as analyze the hygienic-sanitary quality of raw milk produced on dairy farms in a semiarid region of northeastern Brazil.

\section{MATERIALS AND METHODS}

\section{Sample collection and analysis facilities}

Forty-four samples were taken from milk containers at 44 properties in the municipality of Afrânio, which is located in a semiarid region of northeastern Brazil. The collection was performed based on the Instruction Manual for the Collection and Shipping of Milk Samples for Analysis of the Northeast Dairy Herd Management Program. Three samples were taken from each container. One sample in a sterile conical tube was sent for analysis at the laboratories of the Federal University of the São Francisco Valley in the city of Petrolina (state of Pernambuco) for the evaluation of virulence factors of $S$. aureus, standard plate count (SPC - total mesophilic aerobic bacteria), Staphylococcus spp. count, total coliform count, and presence of Pseu- domonas spp. and Streptococcus spp. The other two samples were sent to the PROGENE laboratory of the Rural Federal University of Pernambuco in the city of Recife for the analysis of TBC and SCC using flow cytometry. For the sequencing analyses, the samples were sent to the ACTGene Molecular Analyses Ltd. in the city of Alvorada, state of Rio Grande do Sul, Brazil.

\section{Phenotypic and genotypic identification of}

Staphylococcus spp.

Fifty-eight isolates from the mannitol salt agar $\left(\mathrm{Kasvi}^{\circledR}\right)^{1}$ medium were initially identified as Staphylococcus spp. based on morphological and biochemical (Gram, catalase) characteristics. The DNA of the isolates was extracted and purified using an adapted method [1]. The samples were subsequently submitted to DNA quantification with the aid of a spectrophotometer (Pico 200 model, Picodrop $\left.{ }^{\circledR}\right)^{2}$. Dilution was then performed and all extracted samples had a final concentration DNA concentration of $50 \mathrm{ng} / \mu \mathrm{L}$. The genotypic identification of the 58 Staphylococcus isolates was performed with the nuc [21] and rdr [37] genes.

Analysis of virulence factors in S. aureus

The phenotypic characterization of the biofilmforming capacity of the isolates was performed using the adherence test in microplates. The strain $S$. aureus ATCC 25923 was used as the positive control and the strain S. epidermidis 12228 was the negative control. Absorbance was measured in microplate reader (Expert Plus model, Biochrom $\left.{ }^{\circledR}\right)^{3}$ at $620 \mathrm{~nm}$ using an adapted method [31]. In the molecular characterization of biofilm formation, the amplification reaction of parts of the icaA and icaD genes was performed using a modified method [42, 13].

The resistance profile of the microorganisms was determined using the modified Kirby-Bauer disk diffusion method. The following $\beta$-lactam antibiotics (one cephalosporin and three penicillins) were tested: cephalotin $(30 \mu \mathrm{g})$, ampicillin $(10 \mu \mathrm{g})$, amoxicillin (10 $\mu \mathrm{g})$, and oxacillin $(1 \mu \mathrm{g})\left(\operatorname{Laborclin}^{\circledR}\right)^{4}$. The test was conducted using a standardized protocol [10]. In the genotypic characterization, the amplification reaction of the blaZ gene was performed with an adapted method [35].

\section{Standard plate count}

The standard plate count (SPC) was performed in agar (Himedia $\left.{ }^{\circledR}\right)^{5}$ using the deep plating technique. The plates were incubated in a bacteriological hothouse 
at $37^{\circ} \mathrm{C}$ for $48 \mathrm{~h}$. Plates with 30 to 300 colonies were then selected for counting. The number of colonyforming units (CFUs/mL) was determined as the mean of three experiments multiplied by the inverse of the dilution [2].

\section{Determination of TBC and SCC}

The raw milk samples were collected in flasks containing azidiol pellets and TBC was determined automatically using flow cytometry (Bactocount IBC, 88 Bentley Instruments $\left.{ }^{\circledR}\right)^{6}$, with the results expressed as CFUs/mL. For the determination of SCC, the raw milk samples were collected in flasks containing bronopol pellets and submitted to fluorescence flow cytometry in a somatic cell counter (SomaScope MKII, Delta Instruments $\left.{ }^{\circledR}\right)^{7}$ following the method suggested in Normative Instruction $N^{\circ} 62$ of the Brazilian Ministry of Agriculture and Livestock [9].

Staphylococcus spp. count and total coliform count

The Staphylococcus spp. count was performed using the dilution method following a standardized protocol [2], with a mannitol salt agar ${ }^{1}$ as the medium. The violet red bile medium was used for the quantification of total coliforms [2]. The plates were incubated in a bacteriological hothouse at $37^{\circ} \mathrm{C}$ for $24 \mathrm{~h}$. Plate containing 30 to 300 colonies were selected for counting. The results were corrected for dilution and expressed as CFUs/mL [2].

Presence of Pseudomonas spp. and Streptococcus spp.

Plating with a calibrated Drigalski spatula (10 $\mu \mathrm{L}$ ) was performed in Pseudomonas agar (for fluorescein) $\left(\text { Himedia }^{\circledR}\right)^{5}$ and Todd Hewitt $\left(\mathrm{Kasvi}^{\circledR}\right)^{1}$ medium for the verification of the presence of Pseudomonas spp. and Streptococcus spp., respectively. Amplification of part of the $16 \mathrm{~S} r R N A$ gene was performed for the molecular identification of the Streptococcus spp. isolates. Purification of the polymerase chain reaction (PCR) was then performed with the PureLink ${ }^{\mathrm{TM}}$ Quick gel extraction and PCR purification combo kit (Invitrogen $\left.{ }^{\mathrm{TM}}\right)^{8}$. The samples were sent to a private firm for sequencing (ACTGene Molecular Analyses, Ltd.), using the didesoxy method or Sanger chain termination method. The PHRED program was used to determine the quality of the electropherograms. Sequences with PHRED quality higher than 20 were analyzed using the Basic Local Alignment Search Tool (BLAST) for the confirmation of the species.
Statistical analysis

The Shapiro-Wilk test demonstrated non-normal distribution of the SCC and TBC data, even after log transformation $\left(\log _{10}\right)$. Thus, Spearman's correlation coefficients were calculated for the evaluation of the results of the SPC and flow cytometry. The Statistical Package for the Social Sciences (SPSS, version 20.0 for Windows $)^{9}$ was used for the statistical analyses.

\section{RESULTS}

The molecular identification of the 58 isolates of Staphylococcus spp. was $100 \%$ positive for the nuc gene (S. aureus). Among the isolates, 31\% (18/58) exhibited weak biofilm production, $56.8 \%(33 / 58)$ exhibited moderate production, and $12 \%$ (7/58) were classified as strong biofilm producers. In the molecular analysis of biofilm formation, $39.6 \%(23 / 58)$ of the isolated had the icaA gene, $31 \%$ (18/58) had the icaD gene, and $5.1 \%(3 / 58)$ were positive for the bap gene. Table 1 lists the findings related to phenotypic and genotypic analysis of biofilm formation.

In the method used to determine resistance, $62 \%(36 / 58)$ of the $S$. aureus isolates were resistant to ampicillin, amoxicillin, and penicillin. No cases of resistance to cephalotin or oxacillin were found. Half of the isolates (29/58) did not exhibit the blaZ gene and, among these 29 isolates, eight were resistant to ampicillin, amoxicillin, and penicillin. Among the isolates positive for the gene, nearly all (28/29) were resistant to ampicillin, amoxicillin, and penicillin.

TBC was performed using both the SPC and automated flow cytometry. A range of $1.4 \times 10^{3} \mathrm{CFUs} /$ $\mathrm{mL}$ to $>3.0 \times 10^{5} \mathrm{CFUs} / \mathrm{mL}$ was found based on the SPC and a range of $6 \times 10^{3} \mathrm{CFUs} / \mathrm{mL}$ to $1.5 \times 10^{6} \mathrm{CFUs} / \mathrm{mL}$ was found using flow cytometry. A significant positive correlation was found between the two methods $(\mathrm{r}=$ $0.61, P<0.01$ ). A non-significant correlation was found between the SCC and CFUs/mL determined using flow cytometry $(r=0.15)$. SCC values ranged from $1.8 \times 10^{4}$ $\mathrm{SCs} / \mathrm{mL}$ to $1.3 \times 10^{6} \mathrm{SCs} / \mathrm{mL}$.

The range in the Staphylococcus spp. count was from $1.0 \times 10^{3} \mathrm{CFUs} / \mathrm{mL}$ to $3.5 \times 10^{5} \mathrm{CFUs} / \mathrm{mL}$. Three properties had counts above $3.0 \times 10^{5} \mathrm{CFUs} / \mathrm{mL}$. The total coliform count ranged from $3.5 \times 10^{2} \mathrm{CFUs} / \mathrm{mL}$ to $3.0 \mathrm{x}$ $10^{5} \mathrm{CFUs} / \mathrm{mL}$. None of the samples from the 44 properties exhibited growth for Pseudomonas spp., but 6.8\% (3/44) were positive for Streptococcus spp. For these isolates, the sequencing results identified one isolate as Lactococcus lactis and the others as Enterococcus spp. 
Table 1. Findings related to biofilm production of isolates obtained from raw milk from dairy cows of municipality of Afrânio, semiarid region of northeastern Brazil.

\begin{tabular}{ccc}
\hline Genotypic findings & Quantity & Biofilm production \\
\hline \multirow{2}{*}{$i c a \mathrm{~A}$} & $47.8 \%(11)$ & Weak \\
& $47.8 \%(11)$ & Moderate \\
& $4.3 \%(1)$ & Strong \\
\hline \multirow{ica\mathrm{D}}{*}{ bap } & $50 \%(9)$ & Weak \\
& $44.4 \%(8)$ & Moderate \\
& $5.5 \%(1)$ & Strong \\
\hline \multirow{2}{*}{$i c a \mathrm{D}+i c a \mathrm{~A}$} & $100 \%(3)$ & Weak \\
& $50 \%(9)$ & Weak \\
\hline$i c a \mathrm{~A}+i c a \mathrm{D}+$ bap & $44.4 \%(8)$ & Strong \\
\hline
\end{tabular}

\section{DISCUSSION}

$S$. aureus is the most frequent microorganism isolated from raw milk. It is commonly associated with food poisoning and most frequent pathogen isolated in cases of bovine mastitis [25]. Thus, the control of mastitis through adequate hygiene practices at the time of milking is of the utmost importance, since $S$. aureus is one of the microorganisms that compromise the sanitary quality of milk products.

As shown in Table 1, only two isolates that were positive for the three genes researched had weak biofilm production. Authors state that the formation of biofilm on inert surfaces is highly sensitive to growth conditions [11]. The plate adherence method can be considered a subjective phenotypic technique, since biofilm production by a bacterium depends on a number of factors, such as the conditions to which it is submitted. Moreover, genetic mechanisms determine biofilm production, which were not analyzed in the present study, such as insertion sequences (IS256 and IS257), which can cause the inactivation of the ica operon, and the quorum-sensing system, which is regulated by an operon ( $a g r)$ that has five genes (agrA, agrB, agrC agrD, and $h(d)$, which are responsible for the production and regulation of virulence factors $[6,12,17,22,29]$.

The bap gene was the least frequent among the isolates tested. In a previous study [13], the authors also found low proportions of $S$. aureus strains from bovine mastitis that were positive for this gene. In
$132 \mathrm{~S}$. aureus isolates from cases of bovine mastitis in Poland, all exhibited the icaA and icaD genes and none exhibited the bap gene [39], which suggests that the prevalence of this gene among $S$. aureus isolates is low. In the present study, genes responsible for the production and formation of biofilm in a phenotypic manner were found, suggesting that $S$. aureus isolates could have the potential to adhere to containers used to store milk and produce biofilm. Moreover, the biofilm produced by these isolates could be a virulence factor associated with bovine mastitis in the region, as biofilm is described as a defense system used by bacteria against the immune system of animals and the action of antimicrobial agents [3].

Analyzing the phenotypic and genotypic results of the resistance of the $S$. aureus to the antimicrobial agents tested, no resistance to cephalotin or oxacillin was found, suggesting that these antibiotics are not commonly used on the properties evaluated, although resistance to oxacillin has been reported for $S$. aureus isolated from animals [23, 28]. In contrast, resistance to the beta-lactam antibiotics of the penicillin class was found, which are the most commonly employed antibiotics used to control diseases in dairy herds $[36,40]$.

Fifty percent (29/58) of the isolates did not exhibit the blaZ gene and eight of these 29 isolates were resistant to ampicillin, amoxicillin, and penicillin. Resistance to beta-lactam antibiotics in isolates without the blaZ gene occurs due to other bacterial 
mechanisms [27]. A previous study evaluated the phenotypic (coagulase-negative Staphylococcus isolated from bovine milk) and molecular resistance with a survey of genes (ermA, ermB, erm $C, m s r A$, mecA, icaA, and icaB) responsible for coding diverse mechanisms associated with resistance in Staphylococcus spp. and the results demonstrated that some isolates have three simultaneous mechanisms (blaZ, mecA, and $m s r A$ ) of resistance to antimicrobial agents [35]. Studies have identified the mecC gene, which is a homolog to the $m e c A$ gene, both of which are responsible for the intrinsic resistance to $\beta$-lactam antibiotics [5]. Among the $50 \%$ of isolates that were positive for the blaZ gene, $96.5 \%$ (28/29) were resistant to ampicillin, amoxicillin, and penicillin. This gene is a prevalent finding in studies developed in northeastern Brazil [23,28].

Considering Normative Instruction $n^{\circ} 62$ of the Brazilian Ministry of Agriculture and Livestock, which establishes a limit of up to $3.0 \times 105 \mathrm{CFUs} / \mathrm{mL}$ for TBC in the northern and northeastern regions of the country [9], 50\% (22/44) of the properties are not compliant with the norm based on the SPC and 9\% (4/44) are not compliant based on flow cytometry. Although a substantial correlation was found between the two methods employed for the determination of the TBC, differences stem from factors that can interfere with the count, such as the predominant microbiota in the milk (Gram positive or negative), the size and shape of the bacterial cells, and the aggregation of these cells [38]. Other researchers state that high counts of mesophilic bacteria in milk indicate contamination during the acquisition period due to improper hygienic-sanitary procedures and failure to clean the udders prior to milking [15].

A high SCC is not necessarily related to the TBC in milk, but a high bacterial count (even with the SCC lower than 400,000/mL) implies inadequate hygiene during the milking process [26]. For samples from milk containers, this correlation tends to decrease, as several factors can lead to an increase in the SCC or the release of pathogens in milk. Thus, the homogenization of milk from different cows can lead to an inaccurate reading of the SCC x CFUs relationship. As Normative Instruction $\mathrm{n}^{\circ} 62$ establishes a maximum of $5.0 \times 10^{5}$ somatic cells/ $\mathrm{mL}$ for the northern and northeastern regions of Brazil [9], five of the properties evaluated in the present study would be shut down. Intramammary infection is the factor that most contributes to an increase in the SCC of milk [32]. Thus, the maintenance of the adequate udder hygiene is important to the quality of milk.
The variation in the counts of Staphylococcus spp. demonstrates differences in the quality of milk among the properties. When present in high concentrations $\left(10^{5}\right.$ to $10^{6} \mathrm{CFUs} \mathrm{mL}^{-1}$ or $\left.^{-1}\right)$ and under adequate conditions, these bacteria produce staphylococcal enterotoxins that cause food poisoning when ingested [7]. A high Staphylococcus count is most often related to the occurrence of mastitis in the herd [4]. Differences in this count are related to the management of the milking process, number of cows with mastitis, a lack of refrigeration of the milk, the volume of milk, etc. Handlers are the main carriers of bacteria and disseminators of microbes to milk [41].

With regard to coliforms, $56.8 \%$ of the milk analyzed (25/44) had counts higher than $1.0 \times 10^{3}$ CFUs/mL, which further implies inadequate sanitary practices with the herd and improper hygiene at the time of milking. Although Normative Instruction $n^{\circ}$ 62 [9] does not establish an acceptable number of total coliforms, these microorganisms are indicative of environmental contamination and fecal matter in milk [20].

None of the samples exhibited growth for Pseudomonas spp., which is a psychrotrophic bacterium found in milk as the result of the contamination of the milking equipment or the surface of the udder [14]. The absence of this microorganism may be related to a lack of refrigeration, as milk remains at ambient temperature until delivered to the dairy plant.

Bovines are the hosts of L. lactis, which is one of the main species isolated from raw milk [24]. The presence of Enterococcus spp. suggests inadequate hygienic-sanitary practices during the acquisition of milk. Moreover, the consumption of milk contaminated by these microorganisms is related to scarlet fever and strep throat [41].

\section{CONCLUSION}

The isolation of $S$. aureus in the milk samples analyzed represents a risk for the herd and public health. The detection of virulence factors related to the production of biofilm in some isolates demonstrates the adhesion and biofilm formation capacity on milking utensils and equipment. The present findings underscore the importance of the adequate, continual training of milk producers for the application of good milking practices. On a number of the properties evaluated, the TBC demonstrated incompliance with Normative Instruction $n^{\circ} 62$ of the Brazilian Ministry of Agriculture and Livestock. 
MANUFACTURERS

${ }^{1}$ Kasvi. Curitiba, PR, Brazil.

${ }^{2}$ Picodrop Limited. Hinxton, England,UK.

${ }^{3}$ Biochrom Ltda. Cambridge, England,UK.

${ }^{4}$ Laborclin Ltda. Vargem Grande, PR, Brazil.

${ }^{5}$ HiMedia Laboratories LLC. West Chester, PA, USA.

${ }^{6}$ Bentley Instruments Inc. Chaska, MN, USA.

\begin{abstract}
${ }^{7}$ Delta Instruments. Drachten, Netherlands.
${ }^{8}$ Invitrogen. Carlsbad, CA, EUA.

${ }^{9}$ SPSS Inc. Chicago, IL,USA.
\end{abstract}

Declaration of interest. This manuscript has never been published. The authors are in agreement with the statements and requirements for publication. None of the authors have any conflict of interest to declare.

\section{REFERENCES}

1 Aldous W.K., Pounder J.I., Cloud J.L. \& Woods G.L. 2005. Comparison of six methods of extracting Mycobacterium tuberculosis DNA from processed sputum for testing by quantitative Real-Time PCR. Journal of Clinical Microbiology. 43(5): 2471-2473.

2 APHA - American Public Health Association. 2001. Compendium of methods for the microbiological examination of foods. 4th edn. Washington: APHA, 702p.

3 Antunes A.L.S., Perez L.R.R., Reiter K.C., Secchi C. \& Freitas A.L.P. 2007. Detecção da produção de biofilme em Staphylococcus spp. por Agar Congo Red. Revista de Saúde da UCPel. 1(1): 27-31.

4 Araújo M.M.P., Alves P.D.D., Barbosa F.H.F. \& Rosa C.A. 2009. Qualidade higiênico-sanitária do leite e da água de algumas propriedades da bacia leiteira do município de Luz - MG. Revista de Biologia e Ciências da Terra. 9(2): 154-171.

5 Blair J.M.A., Webber M.A., Baylay A.J., Ogbolu D.O. \& Piddock L.J.V. 2015. Molecular mechanisms of antibiotic resistance. Nature Reviews Microbiology. 13(1): 42-51.

6 Boles B.R. \& Horswill A.R. 2008. agr-Mediated Dispersal of Staphylococcus aureus Biofilms. Plos Pathogens. 4(4): $1-13$.

7 Borges M.F., Nassu R.T., Pereira J.L., Andrade A.P.C. \& Kuaye A.Y. 2008. Perfil de contaminação por Staphylococcus e suas enterotoxinas e monitorização das condições de higiene em uma linha de produção de queijo de coalho. Ciência Rural. 38(5): 1431-1438.

8 Bozo G.A., Alegro L.C.A., Silva L.C., Santana E.H.W., Okano W. \& Silva L.C.C. 2013. Adequação da contagem de células somáticas e da contagem bacteriana total em leite cru refrigerado aos parâmetros da legislação. Arquivo Brasileiro de Medicina Veterinária e Zootecnia. 65(2): 589-594.

9 Brasil. 2011. Ministério da Agricultura, Pecuária e Abastecimento. Instrução Normativa $N^{\circ} 62$ de 29 de dezembro de 2011. Diário Oficial da União, 30 dez. 2011. Seção 1.

10 Clinical and Laboratory Standards Institute (CLSI). 2015. Performance standards for antimicrobial disk and dilution susceptibility test for bacteria isolated from animals; Approved standard. CLSI document M31-A3. 3rd edn. Wayne: Clinical and Laboratory Standards Institute, 99p.

11 Cramton S.E., Gerke C., Schnell N.F., Nichols W.W. \& Gotz F. 1999. The intercellular adhesion (ica) locus is present in Staphylococcus aureus and is required for biofilm formation. Infection and Immunity. 67(10): 5427-5433.

12 Croes S., Deurenberg R.H., Boumans M.L.L., Beisser P.S., Neef C. \& Stobberingh E.E. 2009. Staphylococcus aureus biofilm formation at the physiologic glucose concentration depends on the S. aureus lineage. BMC Microbiology. 9(229): 1-9.

13 Cucarella C., Solano C., Valle J., Amorena B., Lasa I. \& Penadés J.R. 2001. Bap, a Staphylococcus aureus surface protein involved in biofilm formation. Journal of Bacteriology. 183(9): 2888-2896.

14 Decimo M., Morandi S., Silvetti T. \& Brasca M. 2014. Characterization of Gram-negative psychrotrophic bacteria isolated from Italian bulk tank milk. Journal Food Science. 79(10): 2081-2090.

15 Elmoslemany A.M., Keefe G.P., Dohoo I.R. \& Jayarao B.M. 2009. Risk factors for bacteriological quality of bulk tank milk in Prince Edward Island dairy herds. Part 1: Overall risk factors. Journal of Dairy Science. 92(6): 2634-2643.

16 Gargouri A., Hamed H. \& Elfeki A. 2013. Analysis of raw milk quality at reception and during cold storage: Combined effects of somatic cell counts and psychrotrophic bacteria on lipolysis. Journal of Food Science. 78(9): 1405-1411.

17 Gilot P. \& Leeuwen W. 2004. Comparative analysis of agr locus diversification and overall genetic variability among bovine and human Staphylococcus aureus isolates. Journal of Clinical Microbiology. 42(3): 1265-1269.

18 Gottardi C.P.T., Muricy R.F., Cardoso M. \& Schmidt V. 2008. Qualidade higiênica de leite caprino por contagem de coliformes e estafilococos. Ciência Rural. 38(3): 743-748. 
19 Haugaard K., Heringstad B. \& Whist A.C. 2012. Genetic analysis of pathogen-specific clinical mastitis in Norwegian red cows. Journal of Dairy Science. 95(3): 1545-1551.

20 Jayarao B.M., Pillai S.R., Sawant A.A., Wolfgang D.R. \& Hegde N.V. 2004. Guidelines for monitoring bulk tank milk somatic cell and bacterial counts. Journal of Dairy Science. 87(10): 3561-3573.

21 Kateete D.P., Kimani C.N., Katabazi F.A., Okenga A., Okeel M., Nanteza A., Joloba M.L. \& Najjuka F.C. 2010. Identification of Staphylococcus aureus: DNase and mannitol salt agar improve the efficiency of the tube coagulase test. Annals of Clinical Microbiology and Antimicrobials. 9(23): 1-7.

22 Kozitskaya S., Cho S.H., Dietrich K., Marre R., Naber K. \& Ziebuhrl W. 2004. The bacterial insertion equence element IS256 occurs preferentially in nosocomial Staphylococcus epidermidis isolates: Association with biofilm formation and resistance to minoglycosides. Infection and Immunity. 72(2): 1210-1215.

23 Krewer C.C., Amanso E.S., Gouveia G.V., Souza R.L., Costa M.M. \& Mota R.A 2015. Resistance to antimicrobials and biofilm formation in Staphylococcus spp. isolated from bovine mastites in the Northeast of Brazil. Tropical Animal Health Production. 47(3): 511-518.

24 Lafarge V., Ogier G.C., Girard V., Madalen V., Leveau J.Y., Gruss A. \& Buchet A.D. 2004. Raw cow milk bacterial population shifts attributable to refrigeration. Applied Environmental Microbiology. 70(9): 5644-5650.

25 Li L., Zhou L., Wang L., Xue H. \& Zhao X. 2015. Characterization of methicillin-resistant and-susceptible Staphylococcal isolates from bovine milk in northwestern China. Plos One. 10(3): 1-8.

26 Lima M.C.G., Sena M.J., Mota R.A., Mendes E.S., Almeida C.C. \& Silva R.P.P.E. 2006. Contagem de células somáticas e análises físico-químicas e microbiológicas do leite cru tipo $\mathrm{C}$ produzido na região agreste do estado de Pernambuco. Arquivos do Instituto Biológico. 73(1): 89-95.

27 Lowy F.D. 2003. Antimicrobial resistance: the example of Staphylococcus aureus. Journal of Clinical Investigation. 111(9): 1265-1273.

28 Medeiros E.S., França C.A., Krewer C.C., Peixoto R.M., Souza Júnior A.F., Cavalcante M.B., Costa M.M. \& Mota R.A. 2011. Antimicrobial resistance of Staphylococcus spp. isolates from cases of mastitis in buffalo in Brazil. Journal of Veterinary Diagnostic Investigation. 23(4): 793-796.

29 Melchior M.B., Osch M.H., Lam T.J., Vernooij J.C., Gaastra W. \& Fink-Gremmels J. 2011. Extended biofilm susceptibility assay for Staphylococcus aureus bovine mastitis isolates: Evidence for association between genetic makeup and biofilm susceptibility. Journal of Dairy Science. 94(12): 5926-5937.

30 Melo P.C., Ferreira L.M., Nader Filho A., Zafalon L.F., Vicente H.I.G. \& Souza V. 2013. Comparison of methods for the detection of biofilm formation by Staphylococcus aureus isolated from bovine subclinical mastitis. Brazilian Journal of Microbiology. 44(1): 119-124.

31 Merino N., Toledo-Arana A., Vergara-Irigaray M., Valle J., Solano C., Calvo E., Lopez J.A., Foster T.J., Penadés J.R. \& Lasa I. 2009. Proteina A- Mediated multicellular behavior in Staphylococcus aureus. Journal of Bacteriology. 191(3): 832-843.

32 Pales A.P., Santos K.J.G., Figueiras E.A. \& Melo C.S. 2005. A importância da contagem de células somáticas e contagem bacteriana total para a melhoria da qualidade do leite no Brasil. Revista Eletrônica Faculdade Montes Belos, Goiás. 1(2): 162-173.

33 Rice L.B. 2012. Mechanisms of resistance and clinical relevance of resistance to $\beta$-Lactams, Glycopeptides, and Fluoroquinolones. Mayo Clinic Proceedings. 87(2): 198-208.

34 Santos A.S., Pires C.V., Santos J.M. \& Sobrinho-Costa P.S. 2013. Crescimento de micro-organismos psicrotróficos em leite cru refrigerado. Brazilian Journal of Food and Nutrition. 24(3): 297-300.

35 Sawant A.A., Gillespie B.E. \& Oliver S.P. 2009. Antimicrobial susceptibility of coagulase-negative Staphylococcus species isolated from bovine milk. Veterinary Microbiology. 134(1-2): 73-81.

36 Shitandi A. \& Kihumbu G. 2004. Laboratory evaluation of the improved tube test detection limits for $\beta$-lactam residues in Kenyan milk. African Journal of Biotechnology. 3(1): 82-87.

37 Shome B.R., Mitra S., Buhvana M., Krithiga N., Shomes R., Veli D. \& Prabhudas K. 2012. Multiplex PCR for the detection of five important Staphylococcus spp. in bovine subclinical mastitis milk. Indian Journal of Animal Sciences. 82(1): 9-14.

38 Suhren G. \& Reichmuth J. 2000. Interpretation of quantitative microbiological results. Milchwissenschaft. 55(1): 18-22. 
39 Szweda P., Schielmann M., Milewski, S., Frankowsk A. \& Jakubczak A. 2012. Biofilm production and presence of ica and bap genes in Staphylococcus aureus strains isolated from cows with mastitis in the Eastern Poland. Polish Journal of Microbiology. 61(1): 65-69.

40 Taponen S., Simojoki H., Haveri M. \& Pyorala S. 2006. Clinical characteristics and persistence of bovine mastites caused by different species of coagulase-negative staphylococci identified with API or AFLP. Veterinary Microbiology. 115(1-3): 199-207.

41 Tebaldi V.M.R., Oliveira T.LC., Boari C.A. \& Piccoli R.H. 2008. Isolamento de coliformes, estafilococos e enterococos de leite cru provenientes de tanques de refrigeração por expansão comunitários: identificação, ação lipolítica e proteolítica. Ciência e Tecnologia de Alimentos. 28(3): 753-760.

42 Vasudevan P., Nair M.K.M., Annamalai T.A. \& Venkitanarayanan K.S. 2003. Phenotypic and genotypic characterization of bovine mastitis isolates of Staphylococcus aureus for biofilm formation. Veterinary Microbiology. 92(1-2): 79-185.

43 Veh K.A., Klein R.C., Ster C., Keefe G., Lacasse P., Scholl D., Roy J.P., Haine D., Dufour S., Talbot B.G., Ribon A.O.B. \& Maloin F. 2014. Genotypic and phenotypic characterization of Staphylococcus aureus causing persistent and nonpersistent subclinical bovine intramammary infections during lactation or the dry period. Journal of Dairy Science. 98(1): 155-168. 